\title{
Morphology and molecular study of Pterosiphonia arenosa sp. nov. (Rhodomelaceae, Rhodophyta) from Jeju Island, Korea
}

\author{
Myung Sook Kim ${ }^{1, *}$, Su Yeon Kim², Mi Yeon Yang ${ }^{1}$, Byeongseok Kim ${ }^{1}$ and Pilar Díaz-Tapia ${ }^{3}$ \\ ${ }^{1}$ Department of Biology and Research Institute for Basic Sciences, Jeju National University, Jeju 690-756, Korea \\ ${ }^{2}$ Department of Biology, Chungnam National University, Daejeon 305-764, Korea \\ ${ }^{3}$ Departamento de Bioloxía Animal, Bioloxía Vexetal e Ecoloxía, Facultade de Ciencias, University of A Coruña, Campus \\ da Zapateira s/n, 15071 A Coruña, Spain
}

The genus Pterosiphonia is composed of 22 species worldwide and four of these species have been reported in the North-East Asia. In Korea, P. pennata originally described from the Mediterranean Sea has been previously recorded from the southern coast as a widespread species. In order to confirm the same species from Korea and Mediterranean, we observed the morphology of Korean Pterosiphonia specimen and analyzed $r b c L$ sequences for inferring phylogenetic relationships among similar congeners. Korean entity was recognized as a new species, Pterosiphonia arenosa sp. nov. The new species is characterized by ecorticate axes with 7-10 pericentral cells, branches formed every two segments, and coalesced with main axis over 1-1.25 axial segments, and tetrasporangia formed in straight series on determinate branches of the upper parts of erect axes. A phylogenetic analysis of $r b c$ L sequences demonstrated that P. arenos $a$ was distinct from $P$. pennata found in Spain as well as other species. In conclusion, morphological and molecular sequence data indicated that $P$. arenosa sp. nov. has been previously misidentified as P. pennata in Korea.

Key Words: morphology; Pterosiphonia arenosa sp. nov.; P. pennata; rbcL; Rhodophyta; taxonomy

\section{INTRODUCTION}

The genus Pterosiphonia Falkenberg in Schmitz et Falkenberg (1897) was established for a rhodomelacean species based on the type species, Pterosiphonia cloiophylla, having the following characteristics: thallus bilaterally symmetrical differentiated into prostrate and erect systems of indeterminate growth, erect axes with alternately distichous branches of determinate or indeterminate growth, flattened to strongly compressed, and about 1-2 internodes congenital fusions of proximal parts in short laterals with main axes (Maggs and Hommersand 1993). To date, 22 species have been distinguished in Pterosiphonia, occurring in temperate to tropical regions of the Atlantic and Pacific Oceans (Guiry and Guiry 2012). Only four Pterosiphonia species have been reported in the North-East Asia: Pterosiphonia bipinnata (Postels et Ruprecht) Falkenberg (1901), P. pennata (C. Agardh) Sauvageau (1897), P. pinnulata (Kützing) Maggs et Hommersand (1993), and P. tanakae S. Uwai et M. Masuda (1999).

Pterosiphonia pennata is widely reported, but taxonomically confusing (Maggs and Hommersand 1993, Díaz Tapia and Bárbara 2004). This species was originally described by Agardh (1824) based on the materials collected from the warmer areas of the Mediterranean to Atlantic Sea. Pterosiphonia pennata is characterized by pin- (c) This is an Open Access article distributed under the terms of the Creative Commons Attribution Non-Commercial License (http://creativecommons.org/licenses/by-nc/3.0/) which permits unrestricted non-commercial use, distribution, and reproduction in any medium, provided the original work is properly cited.
Received August 18, 2012, Accepted November 15, 2012

*Corresponding Author

E-mail: myungskim@jejunu.ac.kr

Tel: +82-64-754-3523, Fax: +82-64-756-3541 
nate arrangement of short lateral branchlets, ecorticate, and erect axes with 9-11 periaxial cells (Maggs and Hommersand 1993). The species is generally believed to be ubiquitous outside Mediterranean, i.e., in Europe (Maggs and Hommersand 1993), North and South America (Hoffmann and Santelices 1997, Abbott 1999), Africa (John et al. 2004), Australia and New Zealand (Adams 1994, Womersley 2003), Japan and Korea (Lee et al. 1992). However, Maggs and Hommersand (1993) doubted the species' occurrence, noting that its distribution is difficult to assess at present due to confusion between groups of morphologically similar species.

In Korea, there were reported only one Pterosiphonia species that was identified as $P$. pennata (Lee et al. 1992). It was collected at the rocky intertidal zone of a sheltered area from the southern coast of Korea in temperate region. Although erect branches developed connate lateral branches alternately every two segments, the species identification was considered uncertain owing to some extent of differences in dimension (Lee et al. 1992). This might have reflected the possibility of that a different species occurred in Korea and in the Mediterranean, as the specimens inhabited areas far away. Recent collections from Jeju Island, Korea yielded a species apparently belonging to the genus Pterosiphonia, but it should be compared with specimens of $P$. pennata from Spain / Mediterranean Sea. Red algal plastid large subunit of ribulose-1,5-bisphosphate carboxylase / oxygenase $(r b c \mathrm{~L})$ has been used for phylogenetic analysis and for species identification (Kim et al. 2008, 2010, Won et al. 2009). The approach of molecular taxonomy is especially useful for dealing with the species having wide distribution ranges and to investigate the origin of populations on different geographical barriers (Lin et al. 2009). Molecular techniques also allow us to answer questions on determining the species without clear-cut morphological diagnostic criteria. This is the case of the genus Pterosiphonia where several synonymies have been suggested due to the species are distinguished solely based on a few vegetative characters, which overlapping in some species (Rull Lluch 2002, Díaz Tapia and Bárbara 2004, 2011, Gabrielson et al. 2004).

In this study, we investigated rhodomelacean specimens identified as Pterosiphonia pennata both, from Korea and Spain, near by the type locality. We used detailed morphological information and analysis of gene from the plastid $r b c \mathrm{~L}$. The several $r b c \mathrm{~L}$ sequences available for Pterosiphonia (Kim et al. 2010, 2012) allowed us to compare our results directly with those from other species in the genus and with putative relatives. Here, we describe
Pterosiphonia arenosa sp. nov. from Korea based on materials previously labeled as $P$. pennata and conclude that the name $P$. arenosa must be considered for specimen from the northwestern Pacific marine flora.

\section{MATERIALS AND METHODS}

\section{Morphology}

Samples were collected from the intertidal zone of Jeju Island and transported live to the laboratory putting into plastic bottle filled with seawater. The specimens were pressed as a voucher or preserved in $4 \%$ formalin / seawater for morphological study, with the exception of a small piece of thallus used for molecular analysis. Sections were obtained by hand or with the aid of a freezing microtome NK-101-II (Nippon Optical Works Co., Ltd., Tokyo, Japan). The sectioned preparations were stained with $1 \%$ aniline blue acidified with $1 \% \mathrm{HCl}$ and mounted in 25$30 \%$ Karo syrup. Photographs were taken using a Digital Sight DS-Fil camera (Nikon, Tokyo, Japan) attached to a microscope (ECLIPSE 80i; Nikon). The voucher specimen was deposited in the herbaria of Jeju National University (JNUB), Jeju and the National Institute of Biological Resources (KB), Incheon, Korea.

\section{Molecular study}

Total genomic DNA samples were prepared using the LaboPass Tissu Mini kit (Hokkaido System Science, Hokkaido, Japan) following the manufacturer's instructions. For polymerase chain reaction (PCR) amplification and sequencing reaction of $r b c \mathrm{~L}$ gene, primer pairs were used as follows; rbcLF145-rbcLR898 and $r b c$ LF762-rbcLR1442 (Kim et al. 2010). PCR amplification was carried out with a thermal cycler (Techgene Ltd., Duxford, Cambridge, UK) using a TaKaRa Ex Taq reaction kit (Takara Shuzo, Shiga, Japan). PCR was performed with an initial denaturation step at $94^{\circ} \mathrm{C}$ for $4 \mathrm{~min}$, followed by 35 cycles of $1 \mathrm{~min}$ at $94^{\circ} \mathrm{C}, 1 \mathrm{~min}$ at $50^{\circ} \mathrm{C}$, and $2 \mathrm{~min}$ at $72^{\circ} \mathrm{C}$, with a final $7 \mathrm{~min}$ extension cycle at $72^{\circ} \mathrm{C}$. The PCR products were purified with the AccuPrep PCR Purification Kit (Bioneer, Daejeon, Korea) and then sequenced commercially (Macrogen, Seoul, Korea). Both electropherogram outputs from each sample were edited using the program Chromas version 1.45 software (Technelysium Pty Ltd., South Brisbane, Australia).

A total of $26 r b c L$ sequences ( $17 \mathrm{new}$ ) were collated using the multiple-sequence alignment program Se-Al ver- 
sion 2.0a11 (Rambaut 2002) and aligned visually. Plastid $r b c \mathrm{~L}$ sequences of Symphyocladia marchantioides (Harvey) Falkenberg and S. latiuscula (Harvey) Yamada were included as out groups. Collection information and GenBank accession numbers of 17 specimens are listed in Table 1 together with the sequences from our previous study. Phylogenetic analyses were performed using maximum likelihood (ML) by RAxML software (Stamatakis 2006). We used 200 independent tree inferences using -\# option with default -I (automatically optimized subtree pruning and regrafting [SPR] rearrangement) and -c (25 distinct rate categories) options of the program to iden- tify the best tree. To generate bootstrap values for these phylogenies, we used the same program with the same settings and 1,000 replications. In addition, we analyzed all $r b c \mathrm{~L}$ sequences of Pterosiphonia registered in GenBank (GQ252571-252573), but GQ252571 (P. bipinnata) and GQ252573 (P. gracilis) formed a strong clade with Neosiphonia group (data not shown). On the other hand, the case of GQ252572 (P. dendroidea) sequence would be hinted the possibility of a long branch attraction (data not shown). Finally, we removed three $r b c \mathrm{~L}$ sequence data from GenBank to perform phylogenetic analyses using ML.

Table 1. List of species used in this study for $r b c L$ analysis with collection information and GenBank accession numbers

\begin{tabular}{|c|c|c|c|c|}
\hline Taxa & Collection data & Voucher & $\begin{array}{c}\text { GenBank } \\
\text { accession No. }\end{array}$ & Reference \\
\hline \multirow{12}{*}{$\begin{array}{l}\text { Pterosiphonia arenosa } \\
\text { M. S. Kim et B. Kim }\end{array}$} & Hyeopjae, Jeju, Korea; Apr 18, 2007 & M3_10 & JX857412 & This study \\
\hline & Geumneung, Jeju, Korea; Jan 15, 2010 & S105 & JX857413 & This study \\
\hline & Gimnyeong, Jeju, Korea; Jan 21, 2012 & 12pte01 & JX857414 & This study \\
\hline & Geumneung, Jeju, Korea; Mar 7, 2011 & PT01 & JX857423 & This study \\
\hline & Geumneung, Jeju, Korea; Apr 4, 2011 & PT03 & JX857422 & This study \\
\hline & Hyeopjae, Jeju, Korea; May 3, 2011 & PT04 & JX857421 & This study \\
\hline & Hyeopjae, Jeju, Korea; May 3, 2011 & PT05 & JX857420 & This study \\
\hline & Gimnyeong, Jeju, Korea; Dec 27, 2011 & PT06 & JX857419 & This study \\
\hline & Gimnyeong, Jeju, Korea; Jan 21, 2012 & PT07 & JX857418 & This study \\
\hline & Jongdal, Jeju, Korea; Feb 4, 2012 & РT08 & JX857417 & This study \\
\hline & Gosung, Jeju, Korea; Mar 23, 2012 & PT011 & JX857416 & This study \\
\hline & Gimnyeong, Jeju, Korea; Apr 4, 2012 & PT012 & JX857415 & This study \\
\hline \multirow{2}{*}{$\begin{array}{l}\text { P. ardreana Maggs \& Hom- } \\
\text { mersand }\end{array}$} & Lourido, A Coruña, Spain; Jul 14, 2008 & 21372 & JX857427 & This study \\
\hline & San Román, Lugo, Spain; Jul 16, 2008 & 21373 & JX857428 & This study \\
\hline \multirow{2}{*}{$\begin{array}{l}\text { P. cloiophylla (C. Agardh) } \\
\text { Falkenberg }\end{array}$} & Kommetjie, South Africa; Feb 20, 2006 & P2023 & GQ867080 & Kim et al. (2010) \\
\hline & Kommetjie, South Africa; Feb 18, 2006 & P2024 & GQ867081 & Kim et al. (2010) \\
\hline \multirow[t]{3}{*}{$\begin{array}{l}\text { P. complanata (Clemente) } \\
\text { Falkenberg }\end{array}$} & $\begin{array}{l}\text { Cambre, Malpica, A Coruña, } \\
\text { Spain; Jan 12, } 2009\end{array}$ & 21624 & JF967667 & Kim et al. (2012) \\
\hline & San Román, Lugo, Spain; Jan 10, 2009 & 21625 & JF967668 & Kim et al. (2012) \\
\hline & Beganfry, France; Jun 24, 2006 & P732 & GQ867079 & Kim et al. (2010) \\
\hline \multirow{3}{*}{$\begin{array}{l}\text { P. pennata (C. Agardh) } \\
\text { Sauvageau }\end{array}$} & Ártabra, A Coruña, Spain; Jun 6, 2008 & 20940 & JX857426 & This study \\
\hline & $\begin{array}{l}\text { Ensenada de Chanteiro, A Coruña, } \\
\text { Spain; Sep 17, } 2005\end{array}$ & 19607 & JX857424 & This study \\
\hline & La Franca, Asturias, Spain; Oct 6, 2006 & 19754 & JX857425 & This study \\
\hline \multirow[t]{2}{*}{ Pterosiphonia sp. } & Kommetjie, South Africa; Feb 17, 2006 & M9 & JF967665 & Kim et al. (2012) \\
\hline & Kommetjie, South Africa; Feb 19, 2006 & M11 & JF967666 & Kim et al. (2012) \\
\hline $\begin{array}{l}\text { Symphyocladia latiuscula } \\
\text { (Harvey) Yamada }\end{array}$ & Anin, Gangneung, Korea; Feb19, 2011 & CNU884 & JF967652 & Kim et al. (2012) \\
\hline $\begin{array}{l}\text { S. marchantioides } \\
\text { (Harvey) Falkenberg in } \\
\text { Schmitz et Falkenberg }\end{array}$ & $\begin{array}{l}\text { Mataikona, Wairarapa, New Zealand; } \\
\text { Jan 5, } 2010\end{array}$ & ASK006 & GU731229 & Kim et al. (2012) \\
\hline
\end{tabular}




\section{RESULTS}

\section{Pterosiphonia arenosa M. S. Kim et B. Kim, sp. nov. (Fig. 1)}

Description. Thalli epilithius, polysiphonieus, ecorticate, ad saxa per rhizoidia unicellularia in intervallis irregularibus affixae, cellulis pericentralibus abscissis, haptero multicellularia terminantibus; $3-7 \mathrm{~cm}$ alti, atrobrunneo rubrum, prostratus axes cylindratis, cum cellulis pericentralium 7-9, segmentis 110-160 $\mu$ m diametro; erecta axes teres ad leviter compressa, cum cellulis pericentralium 7-10, segmentis 160-210 $\mu \mathrm{m}$ diametro in inferiorem partem, 200-360 $\mu \mathrm{m}$ diametro in medio ad superiorem partem; ramis alternatim distichous cum subacue apices, ferri ad intervalla duo segmentis, leviter incurvatis in superiorem partem, teres determinatum ramulis formans acuti cellulis apicalibus; rami laterals per segmenta 1-1.25 proximalia axe parentali congenite connate; trichoblasts praesens / absens; trichoblasti vegetative deficientibus; tetrasporangia tetraedrica, singulariter per segmentum fertile in ramis ultimis in seriebus rectis longitudinalibus singularibus facta, $100 \mu \mathrm{m}$ diametro, a cellulis tegentibus duas presporangialibus sed nee cellulis tegentibus postsporangialibus circumcineta.

Thalli epilithic, polysiphonous, ecorticate, attached by unicellular rhizoids cut off from pericentral cells, terminating multicellular hapteron; 3-7 cm tall, dark brownish red in color; prostrate axes cylindrical, with 7-9 pericentral cells, segments 110-160 $\mu \mathrm{m}$ in diameter; erect axes terete to slightly compressed, with 7-10 pericentral cells, segments 160-210 $\mu \mathrm{m}$ broad in lower portion, 200-360 $\mu \mathrm{m}$ broad in middle to upper portion; branches alternately distichous with subacute apices, borne at intervals of two segments, slightly incurved in upper portion, terete determinate branchlets forming acute apical cell; lateral branches congenitally fused for proximal 1-1.25 segments with the parental axis; trichoblasts entirely lacking; tetrasporangia tetrahedral, formed one per fertile segment in straight series of ultimate branches, 65-75 $\mu \mathrm{m}$ in diameter, surrounded by two presporangial and one post-sporangial cover cells. Other reproductive structures not observed.

Holotype. JNUB-3PTA1201, tetrasporophyte, collected on Dec 27, 2011 by M. S. Kim and B. Kim (Fig. 1A), deposited in JNUB (the Herbarium of the Department of Biology, Jeju National University, Jeju 690-756, Korea).

Isotypes. JNUB (3PTA1202-3PTA1216), KB (NIBRAL00 0013308-NIBRAL000013310).

Type locality. Gimnyeong, Jeju Island, Korea $\left(33^{\circ} 33\right.$ $\left.28.01^{\prime \prime} \mathrm{N}, 126^{\circ} 45^{\prime} 29.77^{\prime \prime} \mathrm{E}\right)$.

Etymology. The specific epithet was chosen to represent the natural habitat of the discovery collection, where plants are growing on a stone in sandy place.

Korean name. 나래붉은깃

Other specimens examined. Hyeopjae (M3-10, Apr 18, 2007; 3PTA1217-3PTA1221, Apr 19, 2011; 3PTA12223PTA1226, May 3, 2011), Gimnyeong (3PTA1227-3PTA1231, Jan 21, 2012; PT012, Apr 4, 2012), Jongdal (PT08, Feb 4, 2012), Gosung (PT011, Mar 23, 2012), Geumneung (S105, Jan 15, 2010; PT01, Mar 7, 2011; PT03, Apr 4, 2011).

Habitat. Pterosiphonia arenosa was collected at the lower intertidal zone of sheltered area. It often grew in dense tufts on a stone in sandy place intermingled with other species such as Neosiphonia spp.

Morphology. Thalli are 3-7 $\mathrm{cm}$ high, dark brownish red (Fig. 1A). Erect branches are arising irregularly from prostrate axes as dense tufts (Fig. 1B). Plants grow on rocks covered lightly in sand. Thalli have tangled prostrate axes attached by unicellular rhizoids, which are cut off by cross walls from the lower pericentral cells and have discoidal haptera at the terminal portion (Fig. 1C). Prostrate axes are terete, ecorticate, $110-160 \mu \mathrm{m}$ in diameter and possess segment $80-130 \mu \mathrm{m}$ long which consist of a central cell and 7-9 pericentral cells (Fig. 1H). Erect axes are mostly terete and slightly compressed in branching portion, ecorticate, 160-210 $\mu \mathrm{m}$ in diameter, with an alternately distichous branching pattern, bearing numerous determinate and indeterminate branches every two segments, becoming tapered upwards, consisting of 7-10 pericentral cells which are 200-360 $\mu \mathrm{m}$ long and 30-50 $\mu \mathrm{m}$ broad (Fig. 1D \& I-L). Diameter / length ratio of segments is $0.8-1.3$ in prostrate axes and 1.8-2.1 in erect ones. Branches of erect axes are having congenital fusions of proximal parts of 1-1.25 segments with bearing axes (Fig. 1E). Trichoblasts are absent. Lateral branches are determinate, 1.2-2.6 $\mathrm{mm}$ long, mainly arranged alternate at lateral portion or spirally on prostrate axes (Fig. 1E \& F). The upper portion of erect axes is terete, with alternate branches curved inwards. The apical cells are obtuse, 15$20 \mu \mathrm{m}$ long, $10-13 \mu \mathrm{m}$ broad on indeterminate branches, however conic shape, 10-15 $\mu \mathrm{m}$ long, 7-15 $\mu \mathrm{m}$ broad on determinate branches (Fig. 1G). Tetrasporangia are arranged in straight series and formed one per fertile segment in determinate lateral branches of the upper portion of thallus (Fig. 1N). Tetrasporangia are tetrahedral, 65-75 $\mu \mathrm{m}$ in diameter and surrounded by two presporangial and one postsporangial cover cells (Fig. 1M, O \& P). Other reproductive structures were not observed. 
A
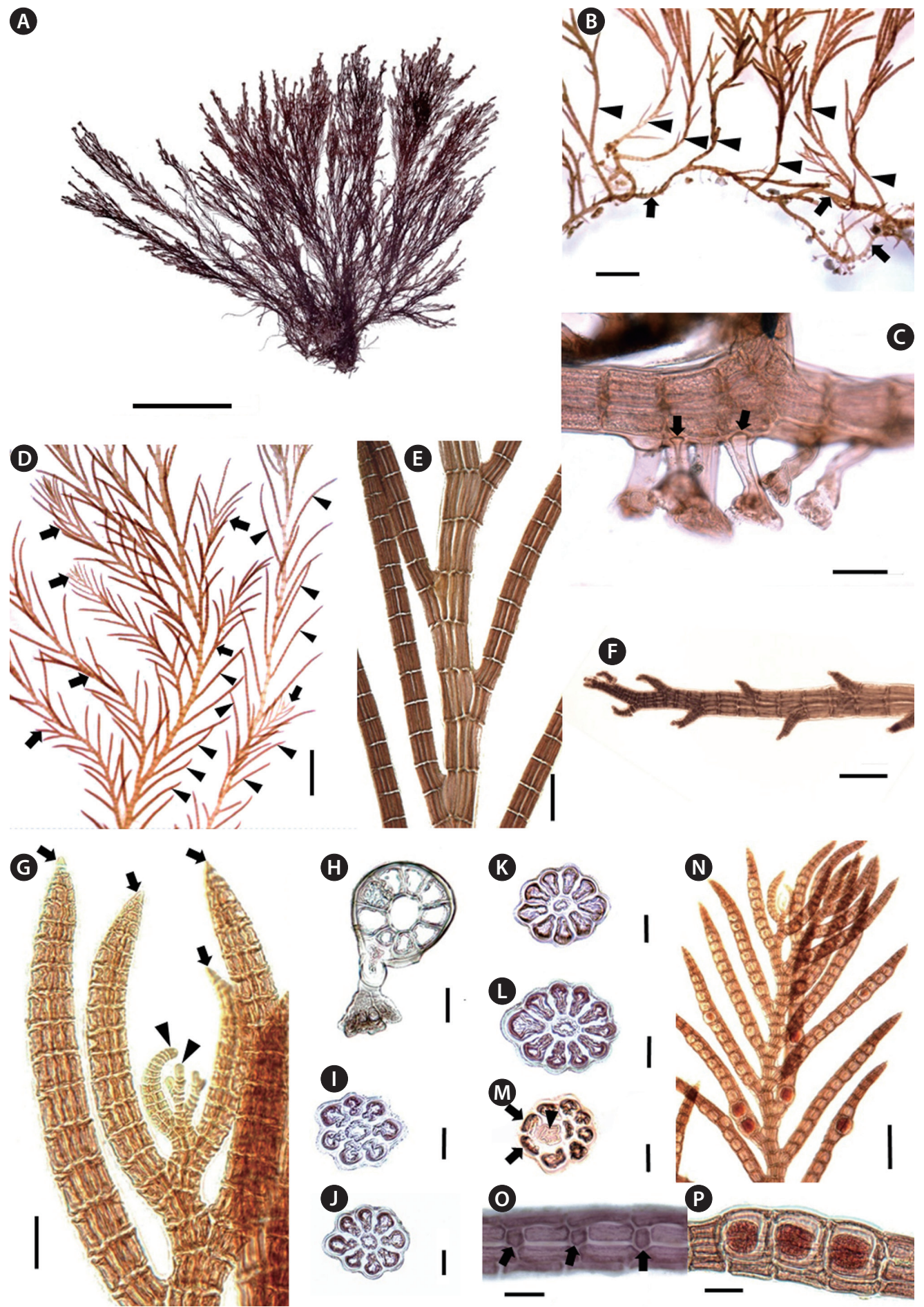

(
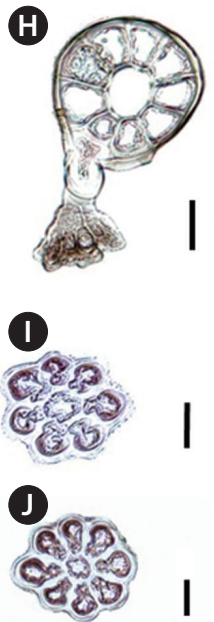

K
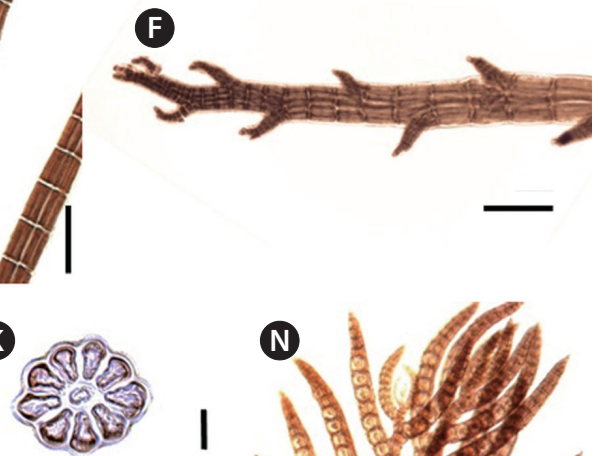

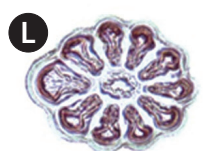

(M)

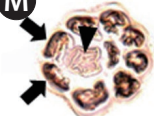

(0)

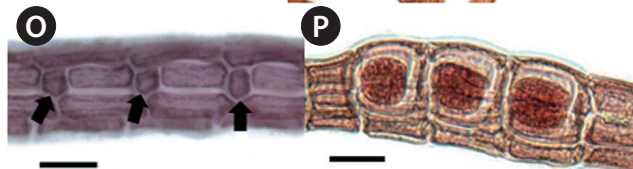

Fig. 1. Pterosiphonia arenosa M. S. Kim \& B. Kim, sp. nov. (A) Holotype specimen (JNUB-3PTA1201, tetrasporophyte, 27 December 2011, Gimnyeong) deposited in the Herbarium of Jeju National University (JNUB), Jeju, Korea. (B) Prostrate axes (arrows) with numerous erect branches (arrowheads). (C) Unicellular rhizoids cutting off from pericentral cells of prostrate axes by cross walls (arrows). (D) Erect branches showing alternately distichous branching pattern: determinate branches (arrowheads) and indeterminate branches (arrows). (E) Branches formed every two segments and coalesced with main axis over 1-1.25 axial segments. (F) Prostrate axes bearing spirally numerous young branches. (G) The apex of erect axes with obtuse apical cells (arrowheads) and determinate branches with conic apical cells (arrows). (H) Cross section of prostrate axes having 9 pericentral cells. (I-L) Cross section of erect axes having 7-10 pericentral cells. (M) Cross section of tetrasporangial branches, having tetrasporangia (arrowhead) and two presporangial cover cells (arrows). (N) Erect branches having tetrasporangia in straight series. (O) Postsporangial cover cells (arrows) of tetrasporangia. (P) Tetrasporangia. Scale bars represent: A, $2 \mathrm{~cm} ; B$ \& D, $1 \mathrm{~mm} ; C, 100 \mu \mathrm{m} ; \mathrm{E}, \mathrm{F} \& \mathrm{~N}, 200 \mu \mathrm{m} ; \mathrm{G}$, $\mathrm{H}, \mathrm{O} \& \mathrm{P}, 50 \mu \mathrm{m} ; \mathrm{I}, \mathrm{J} \& \mathrm{~K}-\mathrm{M}, 30 \mu \mathrm{m}$. 


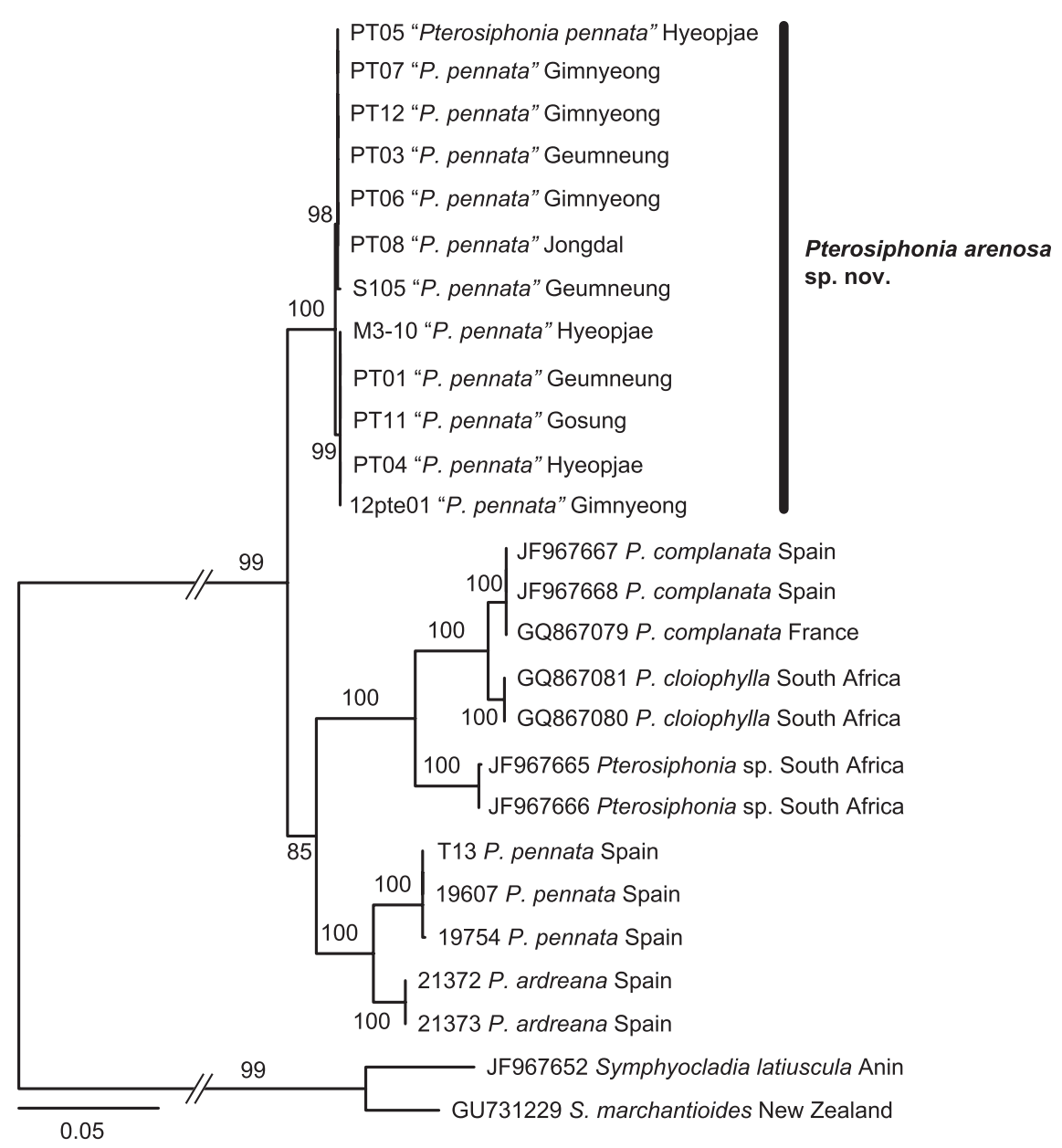

Fig. 2. Maximum likelihood (ML) phylogenetic tree for Pterosiphonia and out group derived from chloroplast $r b c \mathrm{~L}$ sequences. The ML bootstrap values shown above branches are from 1,000 replications.

Molecular analysis. A total of $1,150 \mathrm{bp}$ of $r b c \mathrm{~L}$ were aligned for 26 sequences representing six species of Pterosiphonia, and two species of Symphyocladia as outgroups. Twelve specimens of "P. pennata" from Korea were clearly differed from P. pennata collected from Spain that is close by the type locality region of the Mediterranean Sea. The sequences of $P$. arenosa differed 0-4 bp (0$0.35 \%$ ) within the species, and the specimens from Korea differed by $59-61$ bp (5.13-5.30\%) from those of P. pennata collected from Spain. The sequence divergence within the genus Pterosiphonia ranged from $1.22 \%$ between $P$. complanata and P. cloiophylla to $7.04 \%$ between P. complanata and P. pennata.

In the phylogenetic tree, the genus Pterosiphonia was a monophyletic clade with $99 \%$ bootstrap supports (Fig. 2). The clade of Pterosiphonia consisted of two internodes; one is "P. pennata" specimens from Korea with $100 \%$ bootstrap supports, and the other is composed of five Pterosiphonia species with moderate bootstrap values (85\%) that again diverged in two internodes. The first of these nodes is formed by $P$. complanata from France and Spain, Pterosiphonia sp. from South Africa, and the generitype of the genus Pterosiphonia, P. cloiophylla from South Africa with $100 \%$ bootstrap supports, and the second node consisted of $P$. pennata and $P$. ardreana samples from Spain with $100 \%$ bootstrap supports.

\section{DISCUSSION}

Pterosiphonia arenosa is newly described from Jeju Island, Korea, based on detailed morphological observations and molecular analysis. This new species is epilithic in sand-covered rocks in the sublittoral zone and characterized by the following features: 1) thalli composed of erect and prostrate axes of indeterminate growth, 2) 
ecorticate, 3) 7-10 pericentral cells, 4) branches formed every two segments, 5) determinate branches borne in an alternate-distichous pattern, 6) coalesced with main axis over 1-1.25 axial segments, 7) trichoblasts absent, and 8) tetrasporangia formed in straight series in upper branches of determinate growth. Molecular phylogenetic analysis based on $r b c \mathrm{~L}$ sequences demonstrated $P$. arenosa's distinctness from its congeners, and separated it clearly from the European P. pennata, which was collected from Spain close to the type locality, the Mediterranean Sea. Although $P$. arenosa closely resembles $P$. pennata from Spain in appearance, P. pennata is characterized by having 9-11 pericentral cells, 1.5-2.5 coalesced segments, trichoblasts sometimes present and prostrate axes bearing a spiral arrangement of simple laterals on every third segment (Maggs and Hommersand 1993). As a result, the specimen from Korea previously labeled under the name $P$. pennata (Lee et al. 1992) should be reassigned to $P$. arenosa because its morphological traits agree well with our description of the new species.

In recognizing the species of Pterosiphonia, which currently contains 22 species (Guiry and Guiry 2012), the vegetative characteristics that are viewed as important diagnostic features are 1) number of pericentral cells, 2) the presence or absence of cortication, 3) the degree of coalescence of laterals with their parental axes, and 4) the presence or absence of vegetative trichoblasts (Maggs and Hommersand 1993, Uwai and Masuda 1999a). The diameter / length ratio of segments in prostrate and erect axes is also a valuable characteristic at the species level (Díaz-Tapia and Bárbara 2004). In addition, some morphological traits of reproductive structures could provide additional features, but they are unknown in most species of the genus Pterosiphonia (Díaz Tapia and Bárbara 2011).

In the North-East Asia, four Pterosiphonia species have been previously reported: P. bipinnata (Postels et Ruprecht) Falkenberg, P. pennata (C. Agardh) Sauvageau, P. pinnulata (Kützing) Maggs et Hommersand, and P. tanakae S. Uwai et M. Masuda. Pterosiphonia bipinnata was originally described from Kamchatka, Russia (Falkenberg 1901). Pterosiphonia bipinnata is characterized by large thalli $(>10 \mathrm{~cm})$, axes ecorticate with 11-12(18) pericentral cells, and mostly 3 segments between successive branches (Abbott and Hollenberg 1976). Polysiphonia pinnulata was collected from Genoa, Italy (Kützing 1863) and transferred to Pterosiphonia pinnulata by Maggs and Hommersand (1993). Although the place of type locality is biogeographically separated from the northeast Asia, P. pinnulata with 8-9 pericentral cells has been reported in Japan, for materials previously labeled as $P$. pennata by Okamura (Yoshida 1998). Pterosiphonia pinnulata is characterized by ecorticate axes with 6-7(8) pericentral cells, trichoblasts present, prostrate axes forming a lateral branch every third segments in an apparent spiral, and lateral determinate branches coalesced with main erect axis for 0.5-1.5 axial segments (Maggs and Hommersand 1993). Pterosiphonia tanakae Uwai et Masuda (1999b) was established as a new species on the basis of material collected in Hiroshima Bay, Japan. Pterosiphonia tanakae is characterized by fan-shaped appearance, with 7-10 pericentral cells, corticated axes, lateral branches congenitally fused for proximal 1.5-2.5 segments with the parental axis, and abundant vegetative trichoblasts (Uwai and Masuda 1999b). They mentioned that the presence or absence of vegetative trichoblasts should be considered as a significant taxonomic feature in Pterosiphonia. In $P$. arenosa, vegetative trichoblasts are entirely lacking, which differs from P. tanakae and P. pennata that sometimes have trichoblasts.

A comparison of Pterosiphonia arenosa with the most similar species, P. pennata, reported from various localities in the world is given in Table 2. Although P. arenosa superficially resembles $P$. pennata from Europe in its basically linear outline of erect axes (Maggs and Hommersand 1993, Díaz Tapia and Bárbara 2004), it has been shown in our study to differ in several significant ways (Table 2). Our $r b c \mathrm{~L}$ sequences of $P$. pennata from Spain were different from those of Korean specimens, $P$. areno$s a$. In addition, $P$. pennata was more related to $P$. ardreana from Spain than to P. arenosa from Korea. Pterosiphonia pennata from Spain grows in a habitat closely similar to that of $P$. arenosa in Korea, and both materials are easily confused considering solely morphological traits. However, $P$. pennata is characterized by $9-11$ pericentral cells, sometimes have trichoblasts, and the species usually occurs in extremely wave-sheltered sites, often with moderate to strong current exposure (Maggs and Hommersand 1993). Moreover, other interesting morphological difference is that the tetrasporangia of $P$. pennata from Europe form spiral series on terete extensions of determinate lateral branches from the mid and low parts of the thallus (Díaz Tapia and Bárbara 2004). While P. pennata has been reported from a wide area, including the Atlantic and Pacific Oceans (Guiry and Guiry 2012), our results reveal that these records truly involves more than one species. Therefore, we answered the question on the occurrence of $P$. pennata in the northwest Pacific region, describing $P$. arenosa as a new species endemic from the northwest Pacific region. We demonstrated distinct differences between P. pennata from Spain and P. arenosa from Korea 


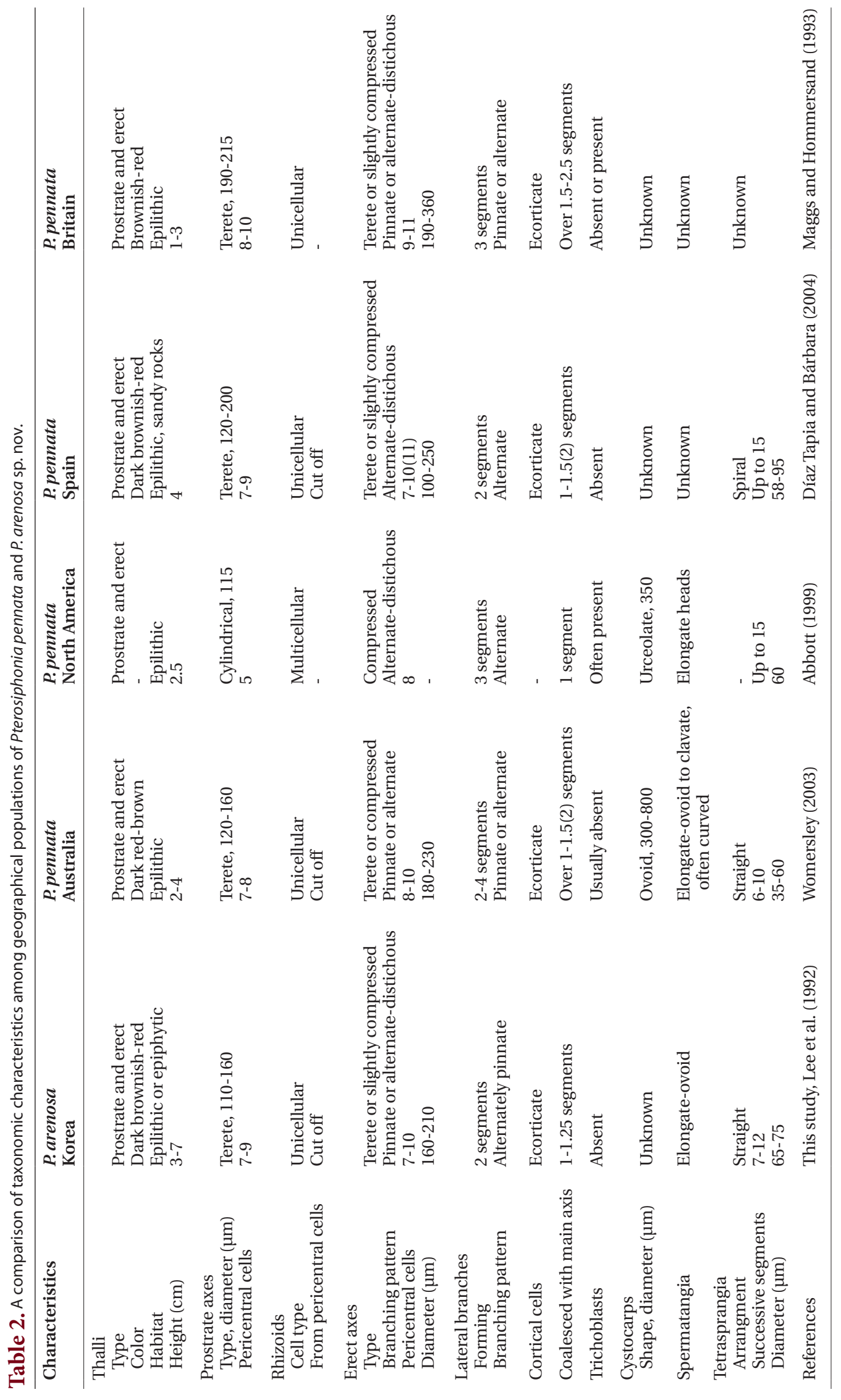


based on the morphological and molecular information. The new species was found from winter to spring in the lower intertidal and subtidal zone, often inhabiting sheltered sites. Detailed collections may provide more information on its distribution within the Pacific area. The distant relationships of $P$. arenos $a$ and $P$. pennata from the putative relatives raise questions about divergence pathways, which will be reinvestigated through additional taxon sampling within the genus. Moreover our results also clarify the distinction between P. cloiophylla from South Africa and $P$. complanata from Europe (2.2\% of sequence divergence), for which the synonymy have been previously suggested (Rull Lluch 2002).

Differences between Pterosiphonia and Symphyocladia have been said to be slight and insubstantial (Kraft and Wynne 1992). However, Ardré (1973) pointed out that further observations on the species of Symphyocladia are necessary before their transfer to Pterosiphonia. According to Uwai and Masuda (1999b) these two genera are clearly distinguished by their juvenile plants. All species of Symphyocladia have flattened thalli in which there is complete, lateral, congenital fusion between branches and their parental axes during early stages of development, resulting in a leaf-like organization (Uwai and Masuda 1999b). However, in juvenile plants of Pterosiphonia apical cells of laterals and the parental axis are completely separate and congenital fusion is found between a few proximal segments of laterals and the axis. This results in a polysiphonous filament-like organization (Uwai and Masuda 1999a).

In conclusion, the analysis of $r b c \mathrm{~L}$ gene in the present study reinforces the taxonomic discrimination of $P$. arenosa from other species in the genus Pterosiphonia. It will be very rewarding to investigate other cosmopoli$\tan$ species of red algae that have phenotypic variation or lack of morphologically clear-cut characters: by comparing type material and molecular analysis. Analyzing more than one gene (e.g., cytochrome c oxidase subunit I [COI] or universal plastid amplicon [UPA] as DNA barcoding marker) will be essential for an accurate assessment of species within large, widespread genera of red algae.

\section{ACKNOWLEDGEMENTS}

This work was supported by the Survey of Indigenous species of Korea from National Institute of Biological Resources (NIBR) to M. S. Kim.

\section{REFERENCES}

Abbott, I. A. 1999. Marine red algae of the Hawaiian Islands. Bishop Museum Press, Hawaii, HI, 477 pp.

Abbott, I. A. \& Hollenberg, G. J. 1976. Marine algae of California. Stanford University Press, Stanford, CA, $827 \mathrm{pp}$.

Adams, N. M. 1994. Seaweeds of New Zealand: an illustrated guide. Canterbury University Press, Christchurch, 360 pp.

Agardh, C. A. 1824. Systema Algarum. Literis Berlingianis, Lund, $312 \mathrm{pp}$.

Ardré, F. 1973. Remarques sur la structure et les affinités des Symphyocladia (Rhodomelacées, Céramiales). Botaniste 56:19-54.

Díaz Tapia, P. \& Bárbara, I. 2004. Pterosiphonia pennata versus $P$. pinnulata (Ceramiales, Rhodophyta) en el noroeste de la Península Ibérica. An. Biol. 26:47-59.

Díaz Tapia, P. \& Bárbara, I. 2011. Sexual structures in Ptilothamnion sphaericum and Pterosiphonia complanata (Ceramiales, Rhodophyta) from the Atlantic Iberian Peninsula. Bot. Mar. 54:35-46.

Falkenberg, P. 1901. Die Rhodomelaceen des Golfes von Neapel und der angrenzenden Meeres-Abschnitte. Fauna und Flora des Golfes von Neapel, Monographie 26. Verlag von R. Friedlander \& Sohn, Berlin, 754 pp.

Gabrielson, P. W., Widdowson, T. B. \& Lindstrom, S. C. 2004. Key to the seaweeds and seagrasses of Oregon and California, north of Point Conception. Phycol. Contrib. 6: 1-181.

Guiry, M. D. \& Guiry, G. M. 2012. AlgaeBase. World-wide electronic publication, National University of Ireland, Galway. Available from: http://www.algaebase.org. Accessed Sep 10, 2012.

Hoffmann, A. \& Santelices, B. 1997. Flora marina de Chile Central: marine flora of central Chile. Ediciones Universidad Católica de Chile, Santiago, 434 pp.

John, D. M., Prud'homme van Reine, W. F., Lawson, G. W., Kostermans, T. B. \& Price, J. H. 2004. A taxonomic and geographical catalogue of the seaweeds of the western coast of Africa and adjacent islands. Nova Hedwigia Beih. 127:1-139.

Kim, M. S., Kim, M., Terada, R., Yang, E. C. \& Boo, S. M. 2008. Gracilaria parvispora is the correct name of the species known as G. bursa-pastoris in Korea and Japan. Taxon 57:231-237.

Kim, M. S., Kim, S. Y. \& Nelson, W. 2010. Symphyocladia lithophila sp. nov. (Rhodomelaceae, Ceramiales), a new Korean red algal species based on morphology and $r b c \mathrm{~L}$ sequences. Bot. Mar. 53:233-241.

Kim, S. Y., Nelson, W. \& Kim, M. S. 2012. A reappraisal of Sym- 
phyocladia (Rhodomelaceae, Rhodophyta), including a new species based on morphology and molecular data. Phycologia 51:531-541.

Kraft, G. T. \& Wynne, M. J. 1992. Heterostroma nereidiis gen. et sp. nov. (Rhodophyta), a dorsiventral rhodomelaceous marine alga from Western Australia. Phycologia 31:16-36.

Kützing, F. T. 1863. Tabulae phycologicae; oder, Abbildungen der Tange. Vol. 13. Gedruckt auf kosten des Verfassers, Nordhausen, 31 pp (in commission bei W. Köhne).

Lee, I. K., Hwang, M. S. \& Oh, Y. S. 1992. Notes on marine algae from Korea (IV). Korean J. Phycol. 7:257-268.

Lin, S. -M., Hommersand, M. H., Fredericq, S. \& De Clerck, O. 2009. Characterization of Martensia (Delesseriaceae, Rhodophyta) based on a morphological and molecular study of the type species, M. elegans, and M. natalensis sp. nov. from South Africa. J. Phycol. 45:678-691.

Maggs, C. A. \& Hommersand, M. H. 1993. Seaweeds of the British Isles. Vol. 1. Rhodophyta. Part 3A. Ceramiales. HMSO, London, 444 pp.

Rambaut, A. 2002. Se-Al: Sequence alignment editor. Available from: http://tree.bio.ed.ac.uk/software/seal/. Accessed Sep 10, 2012.

Rull Lluch, J. 2002. Marine benthic algae of Namibia. Sci. Mar. 66:5-256.

Sauvageau, C. 1897. Note préliminaire sur les algues marines du golfe de Gascogne. J. Bot. Morot 11:166-179, 202-214,
252-257, 263-288, 301-311.

Schmitz, F. \& Falkenberg, P. 1897. Rhodomelaceae. In Engler, A. \& Prantl, K. (Eds.) Die natürlichen Pflanzenfamilien nebst ihren Gattungen und wichtigeren Arten insbesondere den Nutzplanzen unter Mitwirkung zahlreicher hervorragender Fachgelehrten, Teil 1, Abteilung 2. Verlag von Wilhelm Engelmann, Leipzig, pp. 421-480.

Stamatakis, A. 2006. RAxML-VI-HPC: maximum likelihoodbased phylogenetic analyses with thousands of taxa and mixed models. Bioinformatics 22:2688-2690.

Uwai, S. \& Masuda, M. 1999a. Pterosiphonia tanakae (Rhodomelaceae, Ceramiales), a new red algal species from Japan. Phycol. Res. 47:241-250.

Uwai, S. \& Masuda, M. 1999b. Transfer of Pterosiphonia pumila Yendo to the genus Symphyocladia (Rhodomelaceae, Rhodophyta). Phycol. Res. 47:125-133.

Womersley, H. B. S. 2003. The marine benthic flora of southern Australia. Rhodophyta. Part IIID. Ceramiales: Delesseriaceae, Sarcomeniaceae, Rhodomelaceae. Australian Biological Resources Study \& State Herbarium of South Australia, Canberra \& Adelaide, 533 pp.

Won, B. Y., Cho, T. O. \& Fredericq, S. 2009. Morphological and molecular characterization of species of the genus Centroceras (Ceramiaceae, Ceramiales), including two new species. J. Phycol. 45:227-250.

Yoshida, T. 1998. Marine algae of Japan. Uchida Rokakuho Publishing Co., Ltd., Tokyo, pp. 1-2, 1-25, 1-1222. 